Marquette University

e-Publications@Marquette

Marketing Faculty Research and Publications

Marketing, Department of

$1-1-2008$

\title{
Digital Piracy of MP3s: Consumer and Ethical Predispositions
}

Steven Lysonski

Marquette University, steven.lysonski@marquette.edu

Srinivas Durvasula

Marquette University, srinivas.durvasula@marquette.edu

Accepted version. Journal of Consumer Marketing, Vol. 25, No. 3 (2008): 167-178. DOI. (C) 2008 Emerald. Used ith permission. 


\title{
Digital Piracy of MP3s: Consumer and Ethical Predispositions
}

\author{
Steven Lysonski \\ Marketing Department, Marquette University \\ Milwaukee, WI \\ Srinivas Durvasula \\ Marketing Department, Marquette University \\ Milwaukee, WI
}

\begin{abstract}
:
Purpose - Illegal downloading of music has become an inexorable and rampant activity particularly among college students who have been little deterred by industry legal actions. The purpose of this research is to examine the present state of downloading and how ethical orientation and attitudes towards MP3 piracy impact such activities. This paper also aims to use ethical scenarios as a way of understanding the ethical reasoning in illegal downloading.

Design/methodology/approach - Key research questions are proposed that are related to illegal downloading. A sample of 364 university students was used to examine each research question. Statistical results are reported. Findings - The results clearly show that downloading continues at a high rate today driven by strong belief that it is not ethically wrong. Ethical orientation was found to be positively associated with awareness of the social cost of downloading, consequences of downloading, and ethical belief in downloading. Ethical scenarios show that ethical orientation is also associated with downloading activities and with stealing. Other results indicate that respondents believe that their peers are more prone to stealing music and downloading MP3s illegally. Fear of consequences does seem to have an impact on the propensity to download illegally.

Practical Implications - The paper contributes to inform industry representatives that appeal to ethic or guilt are not likely to deter illegal downloading measurably. The use of punishment for downloaders may have a short-term effect but other (more positive) measures are required.
\end{abstract}

Journal of Consumer Marketing, Vol 25, No. 3 (2008): pg. 167-178. DOI. This article is @ Emerald and permission has been granted for this version to appear in e-Publications@Marquette. Emerald does not grant permission for this article to be further copied/distributed or hosted elsewhere without the express permission from Emerald. 
NOT THE PUBLISHED VERSION; this is the author's final, peer-reviewed manuscript. The published version may be accessed by following the link in the citation at the bottom of the page.

Originality/value - No research has examined downloading MP3s in the manner developed in this paper. The paper contributes to a better understanding of consumer behavior among those who download. The results provide insight into a serious problem in the recording industry that is likely to persist in the distant future unless sound measures are developed.

Keywords: Music, Digital storage, Copyright law, Consumer behavior.

\section{Introduction}

"Even as we continue to transform ourselves and transition to the digital marketplace, the music community is still suffering enormously from the impact of Various forms of music theft", said Mitch Bainwol, Chairman and CEO of the RIAA "One of the stories we need to repeatedly tell in the coming months is that illegal downloading and burning continue to compromise the industry's ability to invest in the new brands of tomorrow" (RIAA, www.ria.com).

In recent years, file-sharing networks such as Kazaa, Grokster, EDonkey, and Bit- Torrent, among others have become popular channels to obtain "free" music (Knopper, 2004; Helm, 2005). The internet has irreversibly changed the business model in the music industry (Hiatt and Serpick, 2007). Of particular importance is how the internet has given rise to a ubiquitous activity called downloading as referenced above by the quote from the RIAA (Recording Industry Association of America). Although such downloading can be used for obtaining data, audio or video files, the downloading of music files (aka MP3s) has made the internet a remarkable, and virtually invisible, way of illegally taking title to music without purchasing it.

In the analog era, music could be recorded to tape using a purchased or loaned copy of the music. This process was cumbersome and degraded signal quality as the transfer was made from the source to the copy. In contrast in the digital era, downloading MP3's over the internet is relatively easy, and there is no appreciable loss in quality of downloaded files for most listeners. Fast internet connections, underground peer-to-peer (P2P) networks, and inexpensive digital storage have accelerated the participation in this activity.

The internet and digitization of music have forever altered the landscape regarding the illegal transfer of music from someone's

Journal of Consumer Marketing, Vol 25, No. 3 (2008): pg. 167-178. DOI. This article is (C) Emerald and permission has been granted for this version to appear in e-Publications@Marquette. Emerald does not grant permission for this article to be further copied/distributed or hosted elsewhere without the express permission from Emerald. 
computer to another and the violation of copyright laws. The sites listed above became the lingua franca for those interested in acquiring "free" copyrighted music by engaging in digital piracy (i.e. the illegal downloading of copyrighted MP3s (Helm, 2005)). However, in the past two years, some of the sites have been compelled to prohibit such downloading due to legal rulings against them.

The concern for illegal transfer of music became so contentious that the recording industry, represented by the RIAA, launched a major effort to shut down servers that provided conduits in the flow of the illegal music trade. As evidence of that effort, Napster was forced to cease its practices and become legal in the way it allowed music to be transferred on the internet. Nonetheless, the practice is still rampant through other $\mathrm{P} 2 \mathrm{P}$ sites, and despite the legal Actions taken by the music industry, the activity continues. The RIAA points to various forms of piracy as the primary culprits for 31 percent decline in music sales from 1999 to 2002 (Feuilherade, 2004) and a 6.6 percent decline in $C D$ shipments from record companies to distribution channels for music (RIAA, www.ria.com). They also cite statistics showing that 29 percent of music obtained by listeners in 2004 was in the form of "burned CDs".

Using the power of law stemming from the Digital Millenium Copyright Act, the RIAA has investigated the illegal production and distribution of sound recordings. When the RIAA identifies those infringing copyrighted music through downloading or uploading, subpoenas of internet service providers (ISPs) to identify offenders have resulted in substantial fines to those caught. To date, 11,456 people have been sued by the RIAA of which 2,484 have settled at an average cost of $\$ 3600$ per settlement (Knopper, 2005). The lawsuits, according to some, seem to be failing in stopping illegal downloads as evidenced by the recent crackdown of violators in April 2007 (Bratton, 2007; Cohen, 2004; Knopper, 2004, 2007a, b).

A June 2005 study commissioned by the RIAA found that of those 18 to 54 in age, only 13 percent paid to download music in contrast to only 6 percent in June 2004. In comparison, as many as 12 percent of that sample indicated that they downloaded music illegally from peerto- peer sites (RIAA, www.ria.com). Business Week (2005) reported that 52 percent of college students believe that it is OK to download and swap copyrighted files, even in the workplace. Rolling Stone 
magazine reports that an estimated 8.6 million Americans were exchanging copyrighted songs at one given time in April 2005 which represents an increase of 100 percent from 4.3 million in September 2003 (Knopper, 2005). It is interesting to note that the lawsuits against violators began in September 2003 (Knopper, 2005); the delay in using the law until 2003 was due in part to the frustration of the RIAA in controlling illegal downloading.

The ubiquity of downloading music illegally has not been confined to the USA. In Germany, for example, sales for single CDs dropped by 20 percent in 2001 while in Japan, the decline exceeded 4 percent (Walsh et al., 2003). More than 30 percent of Germans downloaded such music (Walsh et al., 2003). Piracy in Asia is particularly acute given that 90 percent of music sales are for illegal recordings (RIAA, www. ria.com). Attitudes towards piracy seem even more permissive in Asia that in Western cultures (Simmons, 2004). If these trends continue, the music industry will confront a significant transformation, induced by the internet.

Despite the magnitude of the problem, there has been little research exploring the consumer behavior and ethical dimensions related to MP3 piracy among university students. While studies undertaken by trade associations such as the Business Software Alliance (Yahoo News, 2007) periodically provide statistics on what percentage of the youth engage in downloading of pirated MP3 music, they do not help us understand why people engage in such activity and what psychological forces shape people's attitudes toward illegal downloading of MP3 files.

To better understand the motives and factors that encourage digital piracy, research is needed to examine the dynamics of this activity. Such an understanding can assist in developing measures to discourage such piracy. Given the widespread practice of illegal downloading among young adults/college students, the goal of this paper is to examine the mindset of those who are involved in this illegal activity. CEO Bainwoll of the RIAA views the college environment as a problem of enormous proportion because college students are involved in a disproportionate frequency of copyright infringement (Knopper, 2007a). The study was motivated in part by our discussions with students who voiced that taking music off the internet was not really unethical for a host of reasons. Yet, at the 
same time these students were clear in saying that stealing something from a store was dishonest, illegal, and just not right. How do these two conflicting sets of beliefs coexist? What are the ethical dimensions operating? Our paper investigates these questions.

The first part of this paper gives a background discussion of digital piracy followed by various research questions under examination. Specifically, seven research questions will be investigated which focus on downloading activities, ethical and consumer behavior dimensions. Subsequently, the methodology and statistical analyses are presented. The conclusion of the paper provides ideas on the significance of the findings in terms of ethics and implications for deterrence.

\section{Digital Piracy and Illegal Downloading - Research Questions}

\section{Past and Future Intentions of Downloading Activity}

P2P file transfers have made the downloading of music an irresistible temptation for consumers. Various file sharing P2P networks have permitted even the most law abiding consumer to engage in an illegal activity. According to Wilcox (2003), over three billion MP3 files were downloaded each month in 2003. The RIAA recently claimed that 20 billion songs are illegally downloaded each year with a loss off $\$ 4.2$ billion in revenues (Chaffin, 2006). The impact of these downloads was clearly seen in terms of the decline in the sales of prerecorded music CDs and cassettes. Stevans and Sessions (2005) used an econometric time-series model to empirically determine the effect of music downloading on consumer expenditures of recorded music. Their analysis supports the contention that the proliferation of P2P file sharing networks since 2000 has been responsible for a significant decline in music format sales. These researches also concluded that better developed or enforced copyright restrictions constraining consumer who use these networks to share music would reduce the price elasticity of demand for recorded music, thus facilitating price increases by suppliers and increased sales. Their study lends credence to the assertion by the RIAA that illegal downloads are the main reason for dollar value decline of music shipments of cassette tapes and CDs.

Journal of Consumer Marketing, Vol 25, No. 3 (2008): pg. 167-178. DOI. This article is (C) Emerald and permission has been granted for this version to appear in e-Publications@Marquette. Emerald does not grant permission for this article to be further copied/distributed or hosted elsewhere without the express permission from Emerald. 
"The message of the Supreme Court's recent Grokster ruling is clear: both the businesses that encourage theft and the individuals who download songs without permission can be held accountable", said RIAA President Cary Sherman. "Illegal uploading and downloading takes a tremendous toll on our industry as a whole - from songwriters losing their jobs to record stores closing their doors - and directly affects our ability to invest in the next generation of music" (RIAA, www.ria.com). According to RIAA CEO Mitch Bainwols, this ruling is an "important pivotal point" that will see "the emergence of a legal marketplace" (Graham, 2005), yet evidence continues to show that illegal downloading continues at a brisk pace. According to recent statistics, as many as one-third of the teenagers between the ages of eight and 18 continue to download pirated MP3 music (Yahoo News, 2007). Gopal et al. (2004) suggest that the use of the internet to pirate music can be likened to "the genie is now out of the bottle" and that terminating various portals for downloading music illegally will have only limited effect.

Past behavior is likely to influence future behavior producing a habituation effect making illegal downloading seem routine or inconsequential (Ajzen, 2002). A study by Kwong et al. (2003) found that those experienced in buying pirated CDs were more likely to buy more of these pirated products vs those without such experience. Presumably, the same pattern is likely to be found for downloading MP3 files.

Based on past behavior, it is likely that downloading continues at similar levels as the past. The following question examines such activities:

$R Q 1$. What is the present state of illegal downloading among college students in terms of:

RQ1a. Past illegal downloading of music.

RQ1b. Past frequency of illegal downloading of music.

RQ1c. Frequency of paying for music downloads.

RQ1d. Future intention to download music illegally. Are students who have participated in past illegal downloading more likely to download music in the future?

Journal of Consumer Marketing, Vol 25, No. 3 (2008): pg. 167-178. DOI. This article is @ Emerald and permission has been granted for this version to appear in e-Publications@Marquette. Emerald does not grant permission for this article to be further copied/distributed or hosted elsewhere without the express permission from Emerald. 


\section{Beliefs about the Harm Caused by Downloading}

Although the dilemma of illegal downloading continues, few research studies have examined the motives and practices of such consumers. Most studies have focused on the purchase of pirated software (Cheng et al., 1997; Cronan and Al-Rafee, 2007; Lau, 2003, 2006; Peace et al., 2003; Wagner and Sanders, 2001; Sims et al., 1996; Tan, 2002). Bhattacharjee et al. (2003) emphasize that sharing MP3 files is similar to software piracy, yet there is uniqueness to this activity. A study by Freestone and Mitchell (2004) found that Generation $Y$ has identifiable attitudes towards e-ethics and internet related misbehaviors. In particular, they found that Gen $Y$ consumers were more permissive of piracy for the expressed reason that they felt as if they were doing no harm to others, and they were victims of inflated music prices kept artificially high by the music industry. Downloading illegal music and movies files from the internet was seen as the "least wrong" of offenses that could be committed in cyberspace.

Nunes et al. (2004) found that "consumers believe that they cause less harm if their failure to pay prevents a seller from recovering fixed costs than if their failure to pay helps a seller recoup variable costs". No study could be found that asked how down loaders perceive the losses that artists confront and the impact of such losses on the artists' opportunities. Knowing the beliefs that undergird such piracy can give clues into the mindset of the participants in this activity about their sensitivity to losses by artists and the industry. Downloading music may appear as a victimless crime to the perpetrator based on the reasoning that the artist has already been well paid and taking such music is costless.

On the basis of such perspectives, we examine the following research question:

$R Q 2$. What are the beliefs about downloading in terms of the harm that is seen to the artist or industry?

Journal of Consumer Marketing, Vol 25, No. 3 (2008): pg. 167-178. DOI. This article is (C) Emerald and permission has been granted for this version to appear in e-Publications@Marquette. Emerald does not grant permission for this article to be further copied/distributed or hosted elsewhere without the express permission from Emerald. 


\section{Attitudes towards Piracy, Ethical Orientation and Behavioral Intentions}

The morality and social issues of downloading have been given some attention. In a survey by the Gallup Poll (2003), 83 percent of young people said that downloading music for free was morally acceptable while a poll sponsored by the Business Software Alliance found that only 29 percent of young people think illegal copying is wrong (Ishizuka, 2004). Yet, despite such statistics and the pervasiveness of MP3 piracy, research has not explored consumer behavior intentions and ethical issues well, resulting in a dearth of empirical evidence. Traditional moral principles have not provided clarity to the piracy problem (Moor, 1984). Only a few studies could be found examining such issues with some looking at CD copying while the majority of studies focusing on illegal copying of software.

A study by Kwong et al. (2003) examined Chinese consumers' attitudes towards intentions to buy pirated CDs. They found that social benefit of dissemination and anti-big business attitude were positively related to intention to buy pirated CDs while social cost of piracy and ethical belief were negatively related to intention to buy such CDs. In addition to these findings, demographics such as gender and age also were associated with intention to buy pirated CDs. De Matos et al. (2007) found that consumers who viewed honesty as important were less likely to buy counterfeited goods.

Several studies found that students viewed making copies of protected software as socially and ethically acceptable (Oz, 1990; Cohen and Cornwell, 1989; Solomon and O'Brien, 1990). Kini et al. (2000) found that younger consumers were more accepting in the use of pirated software. Furthermore, Harrington (1989) showed that moral reasoning did not seem to have any impact on university students' participation in illegal copying of software. Other studies looking at non-university subjects seemed to derive the same conclusion that "young professionals have no scruples about copying software illegally" (Peace et al., 2003). Whether the same sentiment applies to downloading copyrighted MP3s has not been established empirically.

Gopal and Sanders $(1998,1997)$ urged other researchers to continue to examine behavioral and ethical aspects of software piracy

Journal of Consumer Marketing, Vol 25, No. 3 (2008): pg. 167-178. DOI. This article is (C) Emerald and permission has been granted for this version to appear in e-Publications@Marquette. Emerald does not grant permission for this article to be further copied/distributed or hosted elsewhere without the express permission from Emerald. 
to develop a better understanding of those who participate in this activity. They presented evidence that ethics does have an impact on an individual's propensity in using pirated software. Yet, Glass and Wood (1996) note that many individuals do not view software piracy as an ethical matter. In applying Kohlberg's theory of moral states, Logsdon et al. (1994) found that students did not seem to have developed moral principles regarding their judgments of piracy. The present study is guided by this concern in understanding the ethical dynamics at work for downloading of MP3 files. Do ethics really matter?

Ethics clearly operate in the background when consumers decide to download music illegally since this decision is made within the context of an individual's ethical code or conduct. Knowing the ethical dynamics that operate in the decision to download music can potentially reveal what interventions can be used to discourage such downloading. If it is seen that an ethical indifference exists, more stern measures of threats reinforced by punishment may seem like the best deterrent. If a person has an ethical perspective of idealism, they are more likely to understand that stealing (even if it has become commonplace) is still wrong (Singhapakdi, 2004). We wish to explore the predispositions that govern aspects of downloading especially if students regard downloading of MP3s as stealing vs taking a physical CD from a store without paying for it.

Of significance to this study is that the music industry is now trying to convey a guilt appeal to consumers by suggesting that "innocent" artists are losing income from their intellectual property when consumers take music online for "free". Such an approach is believed to encourage more ethical conduct and reduce illegal downloading. Our study will look at this expectation.

On the basis of insights from ethics in other contexts, our research proposes several other research questions related to the practice and ethics of illegal downloading by college students. Specifically, we investigate the following research questions:

RQ3. What are the attitudes towards piracy of MP3s in terms of the dimensions: social concerns, ethical beliefs, and consequences of downloading?

Journal of Consumer Marketing, Vol 25, No. 3 (2008): pg. 167-178. DOI. This article is (C) Emerald and permission has been granted for this version to appear in e-Publications@Marquette. Emerald does not grant permission for this article to be further copied/distributed or hosted elsewhere without the express permission from Emerald. 
NOT THE PUBLISHED VERSION; this is the author's final, peer-reviewed manuscript. The published version may be accessed by following the link in the citation at the bottom of the page.

RQ4. Are attitudes towards piracy of MP3s and illegal downloading activities affected by ethical orientation? Do students who have a higher ethical orientation have less favorable attitudes towards piracy of MP3s and beliefs about downloading?

RQ5. How are attitudes towards piracy of MP3s and beliefs about downloading related to past downloading behavior and future downloading intentions? Specifically, does fear of punishment have a negative impact on the intention to commit downloading? Does ethical belief affect downloading intentions?

\section{Ethical Decision Making based on Reactions to Scenarios}

One mode of inquiry into how consumers make decisions in ethical matters is to confront them with ethical dilemmas or situations (Lovisky et al., 2007; Lysonski and Gaidis, 1991). The literature reports many studies that have used ethical scenarios as a means of examining the thought process that may operate when a person is confronted with actual ethical situations (see Ellis and Griffith, 2001; Kreie and Cronan, 1998; Thong and Yap, 1998). Scenarios offer some advantages over survey questions since they allow the researcher to control the stimuli exposed to the respondent. As a way of understanding how students react to different ethical situations involving the stealing of music, we developed four different scenarios as featured below. Each scenario provoked the respondent to provide a response reflecting their underlying ethical predisposition. We also asked each respondent to provide a judgment concerning how their peers would respond. These data give a glimpse into the prevailing view they have of the ethics of their friends regarding the theft of music. We also sought to determine if reactions to these scenarios are associated with the internal ethics (i.e. ethical orientation) that each respondent has. The absence of an association would indicate that there is not an ethical consciousness regarding the stealing of music.

RQ6. When asked to make decisions in the ethical scenarios below, how do students respond?

How do students view their peers in making such decisions? Is there a difference between their decision and that of their peers?

Journal of Consumer Marketing, Vol 25, No. 3 (2008): pg. 167-178. DOI. This article is (C) Emerald and permission has been granted for this version to appear in e-Publications@Marquette. Emerald does not grant permission for this article to be further copied/distributed or hosted elsewhere without the express permission from Emerald. 
NOT THE PUBLISHED VERSION; this is the author's final, peer-reviewed manuscript. The published version may be accessed by following the link in the citation at the bottom of the page.

RQ6a. Stealing a CD from a music store with 100 percent certainty of not getting caught.

$R Q 6 b$. Stealing a CD from a music store with some risk that an invisible security camera might observe you.

RQ6c. Not paying for downloading music from a new CD from a major successful artist who you believe is very rich because of two previous successful CDs.

RQ6d. Not paying for downloading music from a new $\mathrm{CD}$ from an independent artist who is very artistic but has not made much money on his/ her previous CD.

$R Q 7$. Is ethical orientation correlated with the decision making scenarios concerning:

$R Q 7 a$. Stealing a CD from a music store with 100 percent certainty of not getting caught.

$R Q 7 b$. Stealing a CD from a music store with some risk that an invisible security camera might observe you.

RQ7c. Not paying for downloading music from a new CD from a major successful artist who you believe is very rich because of two previous successful CDs.

RQ7d. Not paying for downloading music from a new CD from an independent artist who is very artistic but has not made much money on his/her previous CD.

\section{Methodology}

\section{Sample}

University students were used as the sample since they represent a large segment of violators responsible for a "disproportionate amount of copyright infringement and of great concern to the RIAA" (Knopper, 2007b). To obtain the sample, fieldworkers approached college students at several locations throughout the campus such as the university library, student union, and various academic buildings. The fieldworkers visited these locations at various times in the day to reach a broad cross-section of the student population. As students were approached and asked to

Journal of Consumer Marketing, Vol 25, No. 3 (2008): pg. 167-178. DOI. This article is @ Emerald and permission has been granted for this version to appear in e-Publications@Marquette. Emerald does not grant permission for this article to be further copied/distributed or hosted elsewhere without the express permission from Emerald. 
participate in the study, they were guaranteed anonymity by showing that their completed survey would be dropped into a sealed box with a slit on the top. The students were told that they would have 30 minutes to complete the survey. Over 85 percent of the students that were approached volunteered to take the survey. The total sample was 364 representing 156 males and 208 females. The respondents represented a cross section of undergrad class levels, majors, and grade point averages.

\section{Instruments}

To probe the mindset of college students regarding illegal downloading, we used instruments to gauge their ethical orientation in general (i.e. ethical idealism and ethical self concept) and their specific attitudes towards downloading and stealing music (i.e. attitudes towards piracy of MP3s, reactions to ethical scenarios involving stealing music, and beliefs about downloading). The questionnaire consisted of several parts as discussed below.

Ethical idealism was measured with ten items on seven-point Likert scales ( $1=$ strongly agree, $7=$ strongly disagree); this scale was shown to have psychometric soundness by its developers (Forsyth, 1980). Ethical idealism measures the degree to which a person's moral philosophy is rooted in an understanding of the inherent propriety of an action, regardless of its consequences. The items in the scale are based on the assumption that desirable results can be obtained if the "right" action is taken. Low scores on this scale reflect a person who has an idealistic ethical perspective and judges actions in terms of their intrinsic morality without considering their context. This construct is well suited to this study since it measures a student's ethic predisposition in an absolute sense. In our study, an exploratory factor analysis revealed that a one-factor model, where all ethical idealism items are assumed to load on a single factor, explained over 47 percent of the total variance. All items exhibited from factor loadings of 0.4 or above, with seven out of ten items having a loading of above 0.63 . The coefficient alpha for the ten-item ethical idealism scale is 0.87 , implying that the scale is reliable. Based on these supporting psychometric properties of the ethical idealism scale, we formed a composite index of ethical idealism and used this core in subsequent analyses.

Journal of Consumer Marketing, Vol 25, No. 3 (2008): pg. 167-178. DOI. This article is (C) Emerald and permission has been granted for this version to appear in e-Publications@Marquette. Emerald does not grant permission for this article to be further copied/distributed or hosted elsewhere without the express permission from Emerald. 
NOT THE PUBLISHED VERSION; this is the author's final, peer-reviewed manuscript. The published version may be accessed by following the link in the citation at the bottom of the page.

Ethical self concept was measured with one question, "I am an ethical person" using the same seven point scale.

Attitude toward piracy of MP3s was measured with 11 items, all measured using seven- point Likert scales ( $1=$ strongly agree, $7=$ strongly disagree), and consisted of five components:

1 Social cost of piracy (four items). Level of perceived social cost of pirating MP3s.

2 Anti-big business attitude (two items). The desire to "get back" at the recording companies for charging high prices.

3 Social benefit of dissemination (two items). Making music available to the masses who could not otherwise afford such music at the full price.

4 Ethical belief (one item). The ethics of his/her belief in downloading music without paying for it.

5 Consequences (two items). The fear that illegal downloading will result in a personal lawsuit.

The first four components of the attitude toward piracy of MP3s scale were developed by Kwong et al. (2003) for buying pirated music CDs; we modified the wording to apply to pirating MP3's on the internet. These authors also provided evidence for the psychometric validity of the scale. We also added a fifth component that deals with the "consequences" of potential legal action. We included this fifth component given the extent to which legal actions have been proposed as a way to mitigate illegal downloading.

We examined the dimensionality of 11 -item attitudes toward piracy scale using exploratory factor analysis with varimax rotation. A five-factor model representing the above five scale dimensions explained 75 percent of total variance. All items loaded correctly on the appropriate factors. All factor loadings were high (above 0.68). The reliability indices of the social cost and downloading consequences subscales were above 0.75 . The anti-big business attitude scale and social benefits of dissemination scales had coefficient alpha values of approximately 0.60 which were sufficient for research purposes (Malhotra, 2007). In sum, the dimensionality and reliability analyses provide psychometric support for the five-factor model of attitude

Journal of Consumer Marketing, Vol 25, No. 3 (2008): pg. 167-178. DOI. This article is (C) Emerald and permission has been granted for this version to appear in e-Publications@Marquette. Emerald does not grant permission for this article to be further copied/distributed or hosted elsewhere without the express permission from Emerald. 
toward piracy scale. Hence, we formed composite indices for social cost, anti-big business sentiment, social benefits of dissemination, and consequences of downloading, based on responses to individual items of their respective scales.

The survey also asked respondents to make judgments about four ethical scenarios dealing with stealing of music. Each scenario presented different situational factors as follows:

- stealing a CD from a music store with 100 percent certainty of not getting caught;

- stealing a CD from a music store with some risk that an invisible security camera might observe them;

- not paying for downloading music from a new CD from a major successful artist who they believed is very rich because of two previous successful CDs; and

- $\quad$ not paying for downloading a new CD from an independent artist who is very talented, but has not made much money on his/her previous CD.

They were also asked to judge how their peers would react in these same situations so as to understand how they viewed the activities of others. Responses to these measures were obtained using seven-point rating scales ( $1=$ very likely, $7=$ very unlikely). These scenarios are important because they compelled the students to determine their likelihood of stealing music from a store vs stealing music via downloads.

The next part of the survey measured the respondents' beliefs about downloading using two statements:

1 "If you download music illegally, artists do not get royalties. This is the primary way that artists make a living"; and

$2 \quad$ "Some say that record companies do not make a profit on most of their artists. They say they use the profits from major artists to take on riskier, more innovative artists. If they don't profit enough from major artists, they will take far fewer new artists."

Each question required three different response: whether they had heard this before (yes or no), their belief that this was true 
scaled from strongly believe (1) to strongly disbelieve (7), and the influence the idea would have on their downloading music illegally if the idea was true scaled from influence strongly (1) to does not influence (7).

Subsequently, respondents were asked specific questions about their own downloading behavior (past, present, future). Downloading intention was measured asking the respondents about how many songs they were intend to download in the next six months.

\section{Analysis}

\section{RQ1 - present state of downloading activity and intention to download in the future}

Of those in the sample, 94 percent have engaged at one time in downloading music without paying for it. Figure 1 presents histograms featuring frequencies for illegal downloading activities. While 31 percent have not downloaded any music in the last six months, 69 percent have done so at least once and 25 percent have downloaded seven or more songs. When asked how many songs per week (on average) do you download and pay for, the responses were as follows: none (87 percent), one to two songs ( 7 percent), three to six songs ( 3 percent), seven to ten ( 1 percent) and more than ten songs ( 3 percent). Finally, when asked how many songs per week (on average) are you likely to download in the next six months without paying, 43 percent said they would not download any songs while 53 percent intend to download at least one song. Of the sample, 19 percent intended to download seven or more songs in the next six months. Hence, if we assume that the sample is representative of college students, at least 70 percent of the students downloaded illegally in the past six months, only 13 percent pay for downloaded songs and 57 percent plan on downloading more songs in the next six months confirming the Business Week figure reported earlier. Clearly, downloading continues to be rampant.

In performing a correlation analysis between past and future downloading, the intention to download was strongly associated with past illegal downloading at a very high correlation of 0.72.

Journal of Consumer Marketing, Vol 25, No. 3 (2008): pg. 167-178. DOI. This article is (c) Emerald and permission has been granted for this version to appear in e-Publications@Marquette. Emerald does not grant permission for this article to be further copied/distributed or hosted elsewhere without the express permission from Emerald. 
This result confirms the expectation that past behavior is likely to condition future behavior through a habituation effect.

\section{RQ2 - beliefs about downloading}

Interesting findings emerged concerning beliefs about downloading. For the question, "if you download music illegally, artists do not get royalties which is their primary way to make a living", 84 percent had heard this before with a mean belief level of 4.43 (scaled from 1 (strongly believe) to 7 (strongly disbelieve)). When asked how this information influences downloading without paying, the mean was 4.59 (scaled from 1 (strongly influence) to 7 (does not influence)). This result clearly shows that even though the majority has heard that downloading hurts the livelihood of artists, they do not have strong beliefs in the truth of the idea, and these beliefs tend not to have a strong influence on downloading activity. Hence, appealing to students using a guilt appeal is not likely to be effective.

The next question asked was: "Some say record companies do not make a profit on most of their artists. They say that they use the profits from major artists to take on riskier, more innovative artists. If they don't profit enough from major artists, they will take far few newer artists". Only 34 percent of the sample had heard this idea before, and the sample in general did not believe that it was true with a mean rating of 4.67 on the same scale as the first question. Of those who had heard this before, only 32 percent actually believed it. Lastly, when asked to assume that if this idea were true, the sample had an attitude that it would not influence their illegal downloading with a mean of 4.56 .

\section{RQ3 - ethical orientation and attitudes towards piracy of MP3s}

How a student's ethical orientation affects their downloading behavior is an important consideration. We assessed ethical orientation using responses to the scales measuring ethical idealism and ethical self-concept. As shown in Figure 2, the sample had a moderately positive level of ethical idealism (mean $=3: 08$ ) and a favorable ethical self-concept scale as demonstrated by a mean of 2.3. Parenthetically, for both ethical idealism and ethical self- concept, a score below 4 on our seven-point scale implies a favorable opinion.

Journal of Consumer Marketing, Vol 25, No. 3 (2008): pg. 167-178. DOI. This article is (C) Emerald and permission has been granted for this version to appear in e-Publications@Marquette. Emerald does not grant permission for this article to be further copied/distributed or hosted elsewhere without the express permission from Emerald. 
Despite these positive ethical orientations, the results clearly demonstrate a disconnection between ethical orientation and attitudes toward piracy of MP3s. In effect, the mean scores of the dimensions of the attitudes toward piracy construct were not skewed to either strong agreement (mean score close to 1 ) or strong disagreement (mean score close to 7). Instead, the result tended to be in the middle level, indicating a somewhat ambivalent state around the mid point 4 . Specifically, the means were as follows: social cost of piracy (4.18), anti-big business sentiment toward downloading (3.68), social benefits of dissemination (3.59), ethical belief (4.14), and consequences of downloading (4.08).

\section{RQ4 - relationships between ethical orientation, attitudes towards piracy of MP3s and illegal downloading activities}

To probe further into the association between ethical orientation and downloading practices, we examined correlations for the two measures of ethical orientation with attitudes toward piracy and downloading activities. As featured in Table I, there were only three statistically significant correlations for ethical idealism, but none of the correlations were particularly high. Ethical idealism was positively associated with awareness of the social cost of illegal downloading ( $r=$ $0: 26)$, consequences of downloading (0.25), and ethical belief in downloading (0.45). Ethical self-concept had a modest correlation with ethical belief in downloading (0.11) and social cost of downloading (0.12). This table also shows that ethical orientation, either in the form of ethical idealism or ethical self-concept, is not correlated with intentions of future downloading or past downloading. Hence, these results verify the disconnect (as proposed above) between a student's ethical nature and their social and ethical beliefs about downloading.

\section{RQ5 - relationships among downloading intentions, past downloading behavior, attitudes towards piracy of MP3s and beliefs about downloading}

Table II features the results from examining the correlations of future downloading intentions and past behavior with other variables. Only two of the correlations were not significant (i.e. anti-big business sentiment and frequency of paying for downloaded music). All of the

Journal of Consumer Marketing, Vol 25, No. 3 (2008): pg. 167-178. DOI. This article is (C) Emerald and permission has been granted for this version to appear in e-Publications@Marquette. Emerald does not grant permission for this article to be further copied/distributed or hosted elsewhere without the express permission from Emerald. 
correlations were, however, in the expected direction. Clearly, intentions to download are associated with beliefs that there is no social cost to downloading; there are social benefits to downloading; it is ethical to download; and there are legal consequences to downloading. Finally, this intention is also associated with the belief that artists do not get royalties when music is downloaded illegally and record companies will not take on riskier, more innovative artists if they do not profit enough from major artists. We obtained a similar set of correlation results when replacing future downloading intention measure with frequency of downloading in the past. Results in Table II also clearly reveal that fear of punishment (i.e. consequences of downloading) does have a negative impact on the intention to commit downloading.

\section{RQ6 - responses to ethical decisions in scenarios and comparisons to peers}

Provocative results were found concerning the decisions made for the four scenarios whose responses were measured on 1 (very likely) to 7 (very unlikely) scales. For the first scenario dealing with stealing a CD from a store if there were complete certainty of not getting caught, students indicated that they were unlikely to commit such an act with a mean of 6.26. The second scenario on stealing a CD if there were some chance of getting caught had similar results as the first scenario with an overall mean of 6.77.

The responses for the last two scenarios on "stealing" music from the internet, however, were much different. The third scenario, "downloading a CD without paying for it for a successful artist who was rich", showed that students were somewhat likely to "steal" the CD via digital piracy with a mean of 3.38 and neutral, with a mean of 4.08 , for downloading a CD of an artist who was not successful financially. There was a statistically significant mean difference between these two last scenarios. These results, therefore, show that students are in the middle of the scale in expressing their likelihood of downloading such music and are more "considerate" to artists who have been less successful.

To understand how students viewed their peers, they were also asked to provide their impressions of how their peers would act. The results (provided in Table III) indicate that they view their peers as

Journal of Consumer Marketing, Vol 25, No. 3 (2008): pg. 167-178. DOI. This article is (C) Emerald and permission has been granted for this version to appear in e-Publications@Marquette. Emerald does not grant permission for this article to be further copied/distributed or hosted elsewhere without the express permission from Emerald. 
much more likely to commit the unethical act in each scenario: the means were as follows: (5.09 for scenario $1 ; 5.86$ for scenario $2 ; 2.54$ for scenario 3; and 3.09 for scenario 4). Related sample t-tests between the two groups (self vs peers) indicated that all the differences were statistically significant $(p, 0: 05)$. This finding indicates that students believe that their peers are more likely than they to engage in unethical acts concerning stealing music in stores or on line.

\section{$R Q 7$ - correlations of ethical orientation with the decision-making scenarios}

To probe deeper into statistical relationships, we again performed correlation analyses between the two types of ethical orientation and the four scenarios. These are reported in Table IV. The results show that ethical idealism is correlated with all the scenarios at high levels of statistical significance unlike ethical self concept which was only associated with the first two scenarios concerning stealing music from a store. Hence, we can conclude that students' ethics do have an impact on the propensity to engage in stealing music from a store or online, especially their ethical idealism.

\section{Conclusion and Implications}

The study illuminates many areas of concern and supports the widely held belief that downloading by students continues undiminished and that past downloading behavior is predictive of future downloading. Despite the media attention given to the consequences of illegal downloading, students do not seem to be overly concerned. Perhaps, it is due to the invisibility of downloading that hides one's identity and allows the recipient (perpetrator) to feel undetected and not subject to being caught. The results illustrate that ethical orientation was not associated with past or future illegal downloading activity. However, ethical idealism was associated with all the scenarios investigated. Ethical idealists believe that there is a social cost to downloading, that downloading is not ethical, and that there are negative consequences to downloading. Therefore, if ethical idealism can be increased, there is likely to be heightened consciousness about downloading. Is it possible to increase ethical idealism among students? Perhaps ethical idealism is a product of how one is socialized in earlier life. If so, the likelihood of this orientation being heightened is dubious.

Journal of Consumer Marketing, Vol 25, No. 3 (2008): pg. 167-178. DOI. This article is (C) Emerald and permission has been granted for this version to appear in e-Publications@Marquette. Emerald does not grant permission for this article to be further copied/distributed or hosted elsewhere without the express permission from Emerald. 
A compelling finding showed that the intention of downloading was not highly associated with "not paying recording artists their rightful profits is unethical". This result shows the gap between the ethics that one may perceive and their likely actions. In other words, the attitude that one has does not translate well into their behavior. This finding parallels what Astous et al. (2005) found: anti-piracy arguments in terms of ethics were not effective in deterring illegal music downloads. The efficacy of using a guilt appeal as considered by the RIAA is questionable given the findings in our study. Even when students were told that less financially successful artists are hurt personally by illegal downloading, this consideration did not seem to deter their downloading intensions. Hence, the RIAA's ads using a guilt appeal are not likely to be effective as instilling guilt.

The scenario results tell us that people would not steal CDs sold in retail stores, even though the same people are willing to download music files illegally from online sources. One possible reason is that $\mathrm{CDs}$ in a retail store are physical products; they are tangible while digital files are merely digitized signals. Moreover, stealing from a store is more personal with potential fact-to-face contact. Stealing a physical good has higher likelihood of getting caught and getting punished, resulting in shame and threatening penalties. In contrast, when it comes to downloading MP3 digital files, the prospect of being caught is slight. Moreover, downloaders may have the mindset that if every one else is doing it and getting away with doing it, then why should not they participate. The results also show that those who believe they are ethical are unlikely to steal CDs from a store, but this ethical self-concept has no relationship with downloading activities. So, people may not identify ethics as an issue when it comes to nonphysical/tangible goods like digital files, as research on copying software seems to suggest.

Our results clearly show that there is a significant negative correlation between downloading intentions and consequences of being caught downloading. Kwong and Lee (2002) also found that laws can be a strong force in deterring pirating of CDs in Hong Kong. This finding is perhaps the most significant one in this study as it provides insight into how to curb this form of digital piracy. If consequences are viewed as severe, they are likely to lead to fewer downloads.

Obviously, if people suspect that they would be caught and punished,

Journal of Consumer Marketing, Vol 25, No. 3 (2008): pg. 167-178. DOI. This article is (C) Emerald and permission has been granted for this version to appear in e-Publications@Marquette. Emerald does not grant permission for this article to be further copied/distributed or hosted elsewhere without the express permission from Emerald. 
then they are less likely to download illegally. From this perspective, RIAA's decision to file lawsuits against some people, prosecute them, and disseminate such news is likely to have some impact. Indeed, recent statistics seem to suggest a decrease in music file downloading from the internet among the eight-to 18-year-old people (Yahoo News, 2007). Industry groups have taken illegal downloading seriously as witnessed by the RIAA. In representing the music industry, the RIAA has attempted to stop or discourage illegal downloading using two main approaches: education and punishment. The recent crackdown in April 2007 of university students illustrates the punishment approach whereby accused students are given the choice of settling for $\$ 3,000$ to avoid a costly copyright-infringement lawsuit later (Knopper, 2007a, b). By raising awareness through media coverage on illegal downloading, the industry hoped to deter this activity. Notwithstanding this approach, they back up their warnings by seeking to punish the perpetrators.

Ostensibly, the way to deal with MP3 piracy can be likened to a two-pronged approach: the carrot vs the stick. Punishing young people with law suits represents the "stick" approach by the RIAA where offenders are given a penalty to deter them from repeating the behavior and a signal is sent to others that such violations would not be tolerated. While this approach does have merit, one must ask if it is the solution. Lawsuits have not succeeded in stopping or even slowing illegal file sharing according to Knopper (2005). Bigchampagne.com (the research group that follows downloading activity) maintains that P2P sharing has gone up significantly from 5.5 million users a month in 2003 to over 9.3 million in 2006, despite the 20,000 lawsuits by the RIAA (Knopper, 2007a).

Others have recommended that the music industry try to nudge young people into a more cooperative arrangement. Such an arrangement (or "carrot" approach) would make the downloading of music less expensive and more affordable. In fact, the business model developed by Apple (i.e. iTunes) and Napster is a step in that direction since it allows for downloads but at a price. Perhaps, a more attractive business model is needed that can get the cooperation of students who feel that the price per downloaded song is reasonable and fair. Hiatt and Serpick (2007) contend that the industry failed to develop an appropriate business model in 2001 when the first version of Napster

Journal of Consumer Marketing, Vol 25, No. 3 (2008): pg. 167-178. DOI. This article is (C) Emerald and permission has been granted for this version to appear in e-Publications@Marquette. Emerald does not grant permission for this article to be further copied/distributed or hosted elsewhere without the express permission from Emerald. 
was made illegal. Research by Chu and Lu (2007) found that online music providers need to identify and segment their customer to offer attractive prices to each segment. Clearly, more research needs to be conducted in this area to establish the viability of various business model and the prices that would be agreeable to both parties.

Perhaps the reality of illegal downloading should be seen in the context of the main theme in the book The Cheating Culture (Callahan, 2004). Callahan argues that cheating has become an accepted activity in the USA with profound moral implications to the USA. Stealing MP3s on the internet is ostensibly cheating the system, yet the inhibitions to resist this temptation are low. If cheating has become an accepted mode of conduct, deterring illegal trading of MP3 music files on the internet is likely to be a daunting task for the music record industry. These results may also signal the "ethical distance" that Mellema (2003) discusses in referring to the passivity that overcomes one in seeing the moral or ethical violations that one is committing. How to persuade violators to cease illegal downloading when they do not see a significant ethical implication becomes the main question of contention. As noted above, "the genie is now out of the bottle"; how to get him back in may prove to be a difficult task.

\section{Future Research}

Future research needs to explore cross-cultural comparisons. It has been reported that Asians have a different value system regarding the use of copyrighted material such as music. They do not see it as an ethical issue as evidenced by the 90 percent piracy of software in China (Pratt,2005,Lague,2006). Exploring other countries would add more understanding to this issue particularly because illegal downloading is not governed or constrained by national boundaries. The accounting firm KPMG has found that in China, counterfeiting IT products has become a cultural norm (Pratt, 2005). Hence, consumers in some countries such as China may not be culturally attuned to the fact that stealing MP3s online has ethical implications. The RIAA has recently announced a new initiative with the International Federation of the Phonographic Industry to detect illegal downloading across national border. Hence, research on the attitudes of university students in other countries could also determine if the relationships identified in this study are common across cultures.

Journal of Consumer Marketing, Vol 25, No. 3 (2008): pg. 167-178. DOI. This article is (C) Emerald and permission has been granted for this version to appear in e-Publications@Marquette. Emerald does not grant permission for this article to be further copied/distributed or hosted elsewhere without the express permission from Emerald. 
NOT THE PUBLISHED VERSION; this is the author's final, peer-reviewed manuscript. The published version may be accessed by following the link in the citation at the bottom of the page.

Studies are also needed on ethical issues dealing with downloading movies and software illegally. Manly and Markoff (2005) suggest that the "clock is ticking" concerning the likely downloading of movies and television shows illegally on a large scale.

\section{References}

Ajzen, I. (2002), "Residual effects of past on later behavior: habituation and reasoned action perspectives", Personality and Social Psychological Review, Vol. 6 No. 2, pp. 107-22.

Astous, A., Colbert, F. and Montpetit, D. (2005), "Music piracy on the web how effective are anti piracy arguments? Evidence from the theory of planned behaviour", Journal of Consumer Policy, Vol. 28, Spring, pp. 289-310.

Bhattacharjee, S., Gopal, R. and Sanders, G. (2003), "Digital music and online sharing: software piracy 2.0?", Communications of the ACM, Vol. 46 No. 7, pp. 107-11.

Bratton, A. (2007), "Music piracy crackdown nets college kids", San Francisco Chronicle, May 13, available at: www.sfgate.com/cgibin/article.cgi?f=/n/a/2007/05/13/financial/f114935D17.DTL

Business Week (2005), "The stat", November 7.

Callahan, D. (2004), The Cheating Culture, Harcourt, Orlando, FL.

Chaffin, J. (2006), "Fighting the pirates", Financial Times, weekend edition, September 9-10, pp. W1-W2.

Cheng, H., Sims, R. and Teegan, H. (1997), "To purchase or to pirate software: an empirical study", Journal of Management Information Systems, Vol. 13 No. 4, pp. 49-60.

Chu, C.-W. and Lu, H.-P. (2007), "Factors influencing online music purchase intentions in Taiwan", Internet Research, Vol. 17 No. 2, pp. 139-55.

Cohen, E. and Cornwell, L. (1989), "College students believe piracy is acceptable", CIS Educators Forum Proceedings, pp. 2-5.

Cohen, W. (2004), "Lawsuits fail: illegal downloading on the rise despite crackdown", Rolling Stone, No. 955, August 19, p. 32.

Cronan, T. and Al-Rafee, S. (2007), "Factors that influence the intention to pirate software and media", Journal of Business Ethics, Vol. 15, Spring, pp. 14-22.

Journal of Consumer Marketing, Vol 25, No. 3 (2008): pg. 167-178. DOI. This article is @ Emerald and permission has been granted for this version to appear in e-Publications@Marquette. Emerald does not grant permission for this article to be further copied/distributed or hosted elsewhere without the express permission from Emerald. 
NOT THE PUBLISHED VERSION; this is the author's final, peer-reviewed manuscript. The published version may be accessed by following the link in the citation at the bottom of the page.

De Matos, C.A., Ituassu, C. and Rossi, C. (2007), "Consumer attitudes towards counterfeits: a review and extension", Journal of Consumer Marketing, Vol. 24 No. 1, pp. 36-47.

Ellis, T. and Griffith, D. (2001), "The evaluation of IT ethical scenarios using a multidimensional scale", Database for Advances in Information Systems, Vol. 32 No. 1, pp. 75-86.

Feuilherade, P. (2004), "Online piracy devastates music", BBC News, March 3.

Forsyth, D. (1980), "A taxonomy of ethical ideologies", Journal of Personality and Social Psychology, Vol. 39 No. 1, pp. 175-84.

Freestone, O. and Mitchell, W. (2004), "Generation Y attitudes towards eethics and internet- related misbehaviours", Journal of Business Ethics, Vol. 54 No. 2, pp. 121-8.

Gallup Poll (2003), "Moral acceptability of downloading music for free", Gallup Youth Survey, Nos. 97, September.

Glass, S. and Wood, A. (1996), "Situational determinants of software piracy: an equity theory perspective", Journal of Business Ethics, Vol. 15 No. 11 , pp. 1189-98.

Gopal, R. and Sanders, G. (1997), "Preventive and deterrent controls for software piracy",

Journal of Management Information Systems, Vol. 14 No. 4, pp. 29-47.

Gobal, R. and Sanders, G. (1998), "International software piracy: analysis of key issues and impacts", Information Systems Research, Vol. 9 No. 4, pp. 380-97.

Gopal, R., Sanders, G., Bhattacharjee, S., Argawal, M. and Wagner, S. (2004), "A behavioral model of digital music piracy", Journal of Organizational Computing and Electronic Commerce, Vol. 14 No. 2, pp. 89-105.

Graham, J. (2005), "Entertainment firms win file-sharing duel", USA Today, June 28, p. B1.

Harrington, S. (1989), "Why people copy software and create computer viruses: individual characteristics and situational factors", Information Resource Management Journal, Vol. 16 No. 1, pp. 28-37.

Helm, B. (2005), "A hard ride for eDonkey", Business Week, October 24, pp. 90-2.

Journal of Consumer Marketing, Vol 25, No. 3 (2008): pg. 167-178. DOI. This article is (C) Emerald and permission has been granted for this version to appear in e-Publications@Marquette. Emerald does not grant permission for this article to be further copied/distributed or hosted elsewhere without the express permission from Emerald. 
NOT THE PUBLISHED VERSION; this is the author's final, peer-reviewed manuscript. The published version may be accessed by following the link in the citation at the bottom of the page.

Hiatt, B. and Serpick, E. (2007), "The record industry's slow fade", Rolling Stone, June 28, pp.

13-14.

Ishizuka, K. (2004), "Kids: stealing digital data OK", School Library Journal, Vol. 50 No. 8, p. 18.

Kini, R.B., Rominger, A. and Vijayaraman, B.S. (2000), "An empirical study of software piracy and moral intensity among university students", Journal of Computer Information Systems, Vol. 40 No. 3, pp. 62-72.

Knopper, S. (2004), "Lawsuits fail", Rolling Stone, August 19, p. 32.

Knopper, S. (2005), "What happens when the record biz sues you", Rolling Stone, June 16, pp.

26-8.

Knopper, S. (2007a), "RIAA campaign rejected by colleges", Rolling Stone, April 19, p. 12. Knopper, S. (2007b), "RIAA's campus crackdown", Rolling Stone, April 5, p. 15.

Kreie, J. and Cronan, T.R. (1998), "How men and women view ethics", Communications of the ACM, Vol. 41 No. 9, pp. 70-6.

Kwong, K., Yau, O., Lee, J., Sin, L. and Tse, A. (2003), "The effect of attitudinal and demographic factors on intention to buy pirated CDs: the case of Chinese consumers", Journal of Business Ethics, Vol. 47 No. 3, pp. 223-35.

Kwong, T. and Lee, M. (2002), "Behavioral intention model for the exchange mode internet music piracy", Proceedings of the 35th Hawaii International Conference on System Science, pp. 156-60.

Lague, D. (2006), "Small steps in a long fight against piracy", International Herald Tribune, May 17, available at: www.iht. com/articles/2006/05/17/business/soft.php?page =2

Lau, E. (2003), "An empirical study of software piracy", Business Ethics, Vol. 12 No. 3, pp. 23- 245.

Lau, E. (2006), "Factors motivating people toward pirated software", Qualitative Market Research: An International Journal, Vol. 9 No. 4, pp. 404-19.

Logsdon, J.M., Thompson, J.K. and Reid, R.A. (1994), "Software piracy: is it related to level of moral judgment", Journal of Business Ethics, Vol. 13 No. 1, pp. 849-57.

Journal of Consumer Marketing, Vol 25, No. 3 (2008): pg. 167-178. DOI. This article is (C) Emerald and permission has been granted for this version to appear in e-Publications@Marquette. Emerald does not grant permission for this article to be further copied/distributed or hosted elsewhere without the express permission from Emerald. 
NOT THE PUBLISHED VERSION; this is the author's final, peer-reviewed manuscript. The published version may be accessed by following the link in the citation at the bottom of the page.

Lovisky, G., Trevino, L. and Jacobs, R. (2007), "Assessing mangers' ethical decision making: an objective measure of managerial moral judgment", Journal of Business Ethics, Vol. 73 No. 3, pp. 263-86.

Lysonski, S. and Gaidis, W. (1991), "A cross-cultural comparison of the ethics of business students", Journal of Business Ethics, Vol. 10 No. 2, pp. 141-50.

Malhotra, N.K. (2007), Marketing Research: An Applied Orientation, 5th ed., Prentice-Hall, Upper Saddle River, NJ.

Manly, L. and Markoff, J. (2005), "Steal this show", New York Times, January 30 , p. 21.

Mellema, G. (2003), "Responsibility, taint, and ethical distance in business ethics", Journal of Business Ethics, Vol. 47 No. 2, pp. 125-35.

Moor, J.H. (1984), "What is computer ethics", Metaphilosophy, Vol. 16 No. 4, pp. 266-75.

Nunes, J., Hsee, C. and Weber, E. (2004), "Why are people so prone to steal software? The effect of cost structure on consumer purchase and payment intentions", Journal of Public Policy and Marketing, Vol. 23 No. 1, pp. 43-53.

Oz, E. (1990), "The attitude of managers-to-be toward software piracy", OR/MS Today, Vol. 17 No. 4, pp. 24-6.

Peace, A., Galleta, D. and Thong, J. (2003), "Software piracy in the workplace: a model and empirical test", Journal of Management Information Systems, Vol. 20 No. 1, pp. 153-77.

Pratt, M. (2005), "China syndrome", Computerworld, November 7, available at: www.computerworld.com/ governmenttopics/government/legalissues/story/0,10801, 105956,00.html

Simmons, L. (2004), "An exploratory analysis of software piracy using crosscultural data", International Journal of Technology Management, Vol. 28 No. 1, pp. 139-48.

Sims, R., Cheng, H. and Teegan, H. (1996), "Toward a profile of student software piraters", Journal of Business Ethics, Vol. 15 No. 8, pp. 83949.

Singhapakdi, A. (2004), "Important factors underlying ethical intentions of students: implications for marketing education", Journal of Marketing Education, Vol. 26 No. 3, pp. 261-70.

Journal of Consumer Marketing, Vol 25, No. 3 (2008): pg. 167-178. DOI. This article is (C) Emerald and permission has been granted for this version to appear in e-Publications@Marquette. Emerald does not grant permission for this article to be further copied/distributed or hosted elsewhere without the express permission from Emerald. 
Solomon, S.L. and O'Brien, J.A. (1990), "The effect of demographic factors on attitudes toward software piracy", Journal of Computer Information Systems, Vol. 30 No. 3, pp. 41-6.

Stevans, L. and Sessions, D. (2005), "An empirical investigation into the effect of music downloading on the consumer expenditures of recorded music: a time series approach", Journal of Consumer Policy, Vol. 28 No. 3, pp. 311-24.

Tan, B. (2002), "Understanding consumer ethical decision making with respect to purchase of pirated software", Journal of Consumer Marketing, Vol. 19 No. 2, pp. 96-111.

Thong, J. and Yap, C.S. (1998), "Testing an ethical decision-making theory: the case of softlifting", MIS Quarterly, Vol. 15 No. 1, pp. 213-37.

Wagner, S. and Sanders, G. (2001), "Considerations in ethical decisionmaking and software piracy", Journal of Business Ethics, Vol. 29 Nos 1/2, pp. 161-7.

Walsh, G., Mitchell, V., Frenzel, T. and Wiedmann, K. (2003), "Internetinduced changes in consumer music procurement behavior", Marketing Intelligence and Planning, Vol. 21 No. 5, pp. 305-17.

Wilcox, J.K. (2003), "Where have all the CD's gone", Sound and Vision, June, pp. 87-9.

Yahoo News (2007), "Illegal downloading on downward track among US youth: survey", available at:

http://news.yahoo.com/s/afp/20070522/tc_afp/lifestyleusitcrime;_ylt

= AtWRo3IFh0Bfbmrlt TGosIYjtBAF (accessed June 13, 2007).

\section{Further Reading}

Cohen, E. (1989), "College students believe piracy is acceptable", Journal of Information Systems Education, Vol. 1 No. 3, pp. 23-34.

\section{Corresponding Author}

Steven Lysonski can be contacted at: s.lysonski@marquette.edu

Journal of Consumer Marketing, Vol 25, No. 3 (2008): pg. 167-178. DOI. This article is (c) Emerald and permission has been granted for this version to appear in e-Publications@Marquette. Emerald does not grant permission for this article to be further copied/distributed or hosted elsewhere without the express permission from Emerald. 
NOT THE PUBLISHED VERSION; this is the author's final, peer-reviewed manuscript. The published version may be accessed by following the link in the citation at the bottom of the page.

\section{Executive Summary and Implications for Managers and Executives}

This summary has been provided to allow managers and executives a rapid appreciation of the content of this article. Those with a particular interest in the topic covered may then read the article in toto to take advantage of the more comprehensive description of the research undertaken and its results to get the fill benefit of the material present.

Recent years have seen a huge growth in popularity of file sharing networks for the purpose of illegally downloading music. Faster internet connections and high quality copying and easy storage of MP3 digital files have all served to hasten the activity. According to the Recording Industry Association of America (RIAA) piracy is to blame for a fall in both music sales and the number of compact discs (CDs) distributed by record companies. It claims that $\$ 4.2$ billion revenues are lost each year as a result of the 20 billion songs illegally downloaded.

Studies commissioned by the RIAA have shown college students to be main perpetrators of MP3 piracy. Even though the organization has prosecuted many thousands of offenders, the problem remains on the up. In April 2005, for example, 8.6 million Americans swapped copyrighted songs at any one given time. This figure showed a 100 percent increase on the 4.3 million engaging in this activity 19 months earlier.

\section{What Motivates Piracy?}

Previous studies have suggested that past action provides a reliable pointer towards future intention. There is empirical evidence that those with experience of obtaining copied CDs are likelier to buy pirated products than those without the experience. One suggestion is that such behavior is habitual and in this context downloading becomes a routine activity.

Sharing MP3 files is considered similar to software piracy in many respects. However, those involved point to inflated prices set by the music industry to justify their actions. Such individuals also believe that artists are financially well rewarded at the outset, making piracy a victimless crime. But the RIAA points out that songwriters lose jobs, stores close and investment in new artists is slashed as a direct result of illegal downloading.

Lysonski and Durvasula claim that little research has been conducted into the ethical aspect of illegal file copying among university students. But the limited evidence does suggest that the majority of young people regard the illegal downloading of software as socially and morally acceptable. One aim of the present study is to determine if the same sentiments apply to pirating MP3 music files. The authors believe that knowing the "ethical

Journal of Consumer Marketing, Vol 25, No. 3 (2008): pg. 167-178. DOI. This article is (C) Emerald and permission has been granted for this version to appear in e-Publications@Marquette. Emerald does not grant permission for this article to be further copied/distributed or hosted elsewhere without the express permission from Emerald. 
NOT THE PUBLISHED VERSION; this is the author's final, peer-reviewed manuscript. The published version may be accessed by following the link in the citation at the bottom of the page.

dynamics that operate in the decision to download music" might help identify effective means of deterring such activities.

\section{Study and Findings}

In the present study, the main objective is to measure the general ethical orientation of university students and their specific attitudes towards the illegal downloading of music. Participants were also asked to reveal information about their past, present and future downloading behavior. Of the 364 survey participants, 208 were female and 156 male. The authors explored a range of questions and the survey findings indicated:

- Strong correlation between past behavior and future intention in relation to illegal downloading.

- The majority were not convinced that their behavior was harmful to the music industry or that record companies use profits from major artists to fund new talent. This suggested that an appeal to the conscience might have a limited impact at best.

- That respondents possessed moderate levels of ethical idealism and ethical self concept. However, a divide was evident between this positive ethical orientation and participant behavior or future intention.

- Evidence of belief that there are social benefits but no social costs to downloading. It was felt that downloading is ethical but the legal consequences of doing so were acknowledged. Lysonski and Durvasula claim that this suggests that fear of punishment could prove an effective deterrent.

In addition, participants were asked to state how they and their peers would respond in four ethical scenarios presented to them. Most students indicated that they would not steal a CD from a store, regardless of the degree of likelihood of getting caught. However, they were somewhat likely to illegally download the CD in MP3 format. It is presumed that the difference is to some extent due to the respective composition of CDs and digital files. One assumption is that people do not regard illegally obtaining intangible items as a moral issue.

Respondents indicated a neutral attitude towards downloading a CD of an artist not commercially successful. The authors feel that students may therefore be more sympathetic where unknown performers are concerned.

In each of the scenarios, the participants believed that their peers would be more likely to act unethically.

Journal of Consumer Marketing, Vol 25, No. 3 (2008): pg. 167-178. DOI. This article is @ Emerald and permission has been granted for this version to appear in e-Publications@Marquette. Emerald does not grant permission for this article to be further copied/distributed or hosted elsewhere without the express permission from Emerald. 
NOT THE PUBLISHED VERSION; this is the author's final, peer-reviewed manuscript. The published version may be accessed by following the link in the citation at the bottom of the page.

The low level of concern about the potential consequence of digital piracy is a likely reflection of the "invisible nature" of the activity. Those who engage feel that detection is unlikely and they take further solace from knowing that many others are behaving likewise. This helps diminish any guilt feelings.

Lysonski and Durvasula found a link between ethical idealism and the four scenarios presented to the survey participants. They believe that increasing ethical realism might therefore appeal to the conscience of those who illegally download MP3 files. But ethical idealism may result from earlier socialization so it is debatable whether such an objective could be achieved. Furthermore, previous investigations have shown ethics to be an ineffective weapon in the fight against piracy. The existence of principles and the knowledge that action might harm less successful artists did little to deter behavior or future intention.

\section{Implications and Further Research}

A "carrot and stick" approach has been suggested as providing the best way forward. Studies in Hong Kong found strong laws discourage CD piracy and the authors believe that the threat of severe punishment may help tackle the problem elsewhere. Any optimism is nevertheless tempered by the knowledge that RIAA lawsuits have not succeeded in even slowing the download rate.

Since the cost of purchasing songs remains an issue, many believe that making downloads more affordable might hold the key. Apple's iTunes and the legalization of Napster are examples of such a model but wider acceptance of the cost is needed if any significant impact on piracy is to result. Any scope to offer attractive prices may depend on an online music provider's ability to identify and segment its market.

Ultimately, however, the authors believe that discouraging online piracy will remain a considerable challenge if people do not accept the moral implications of engaging in such behavior.

Future research involving college students from other countries may help determine if findings here have significance elsewhere. Comparison between cultures may also prove informative, especially given that piracy is not unique to the USA or restricted by national boundaries. Studies in Asia have indicated that piracy is widespread and motivated by such as anti-big business sentiment. Consumers in countries like China seemingly do not perceive any moral dimension to illegally using copyrighted material.

(A précis of the article "Digital piracy of MP3s: consumer and ethical predispositions". Supplied by Marketing Consultants for Emerald.)

Journal of Consumer Marketing, Vol 25, No. 3 (2008): pg. 167-178. DOI. This article is (c) Emerald and permission has been granted for this version to appear in e-Publications@Marquette. Emerald does not grant permission for this article to be further copied/distributed or hosted elsewhere without the express permission from Emerald. 
NOT THE PUBLISHED VERSION; this is the author's final, peer-reviewed manuscript. The published version may be accessed by following the link in the citation at the bottom of the page.

\section{Appendix}

\section{Figure 1: Past and Future Downloading behavior}

(a) \# songs downloaded in the last 6 months illegally

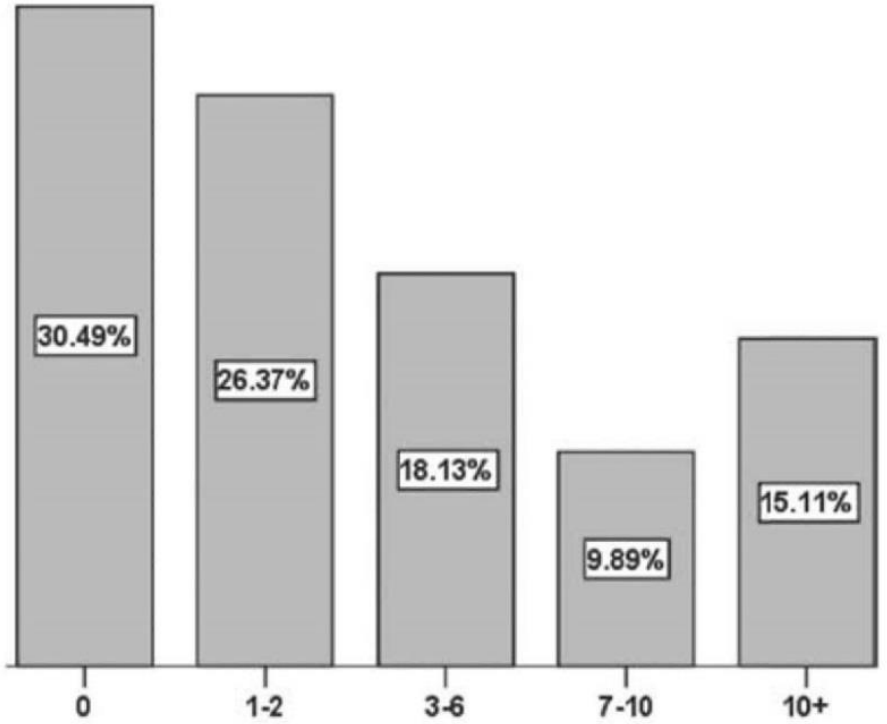

(b) \# Songs downloaded per week with payment

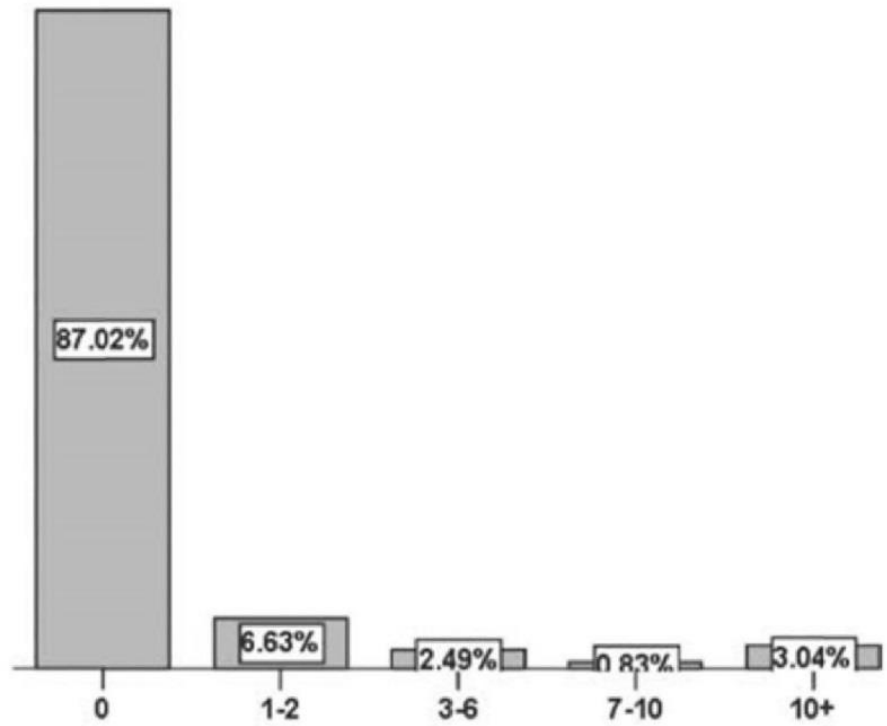

Journal of Consumer Marketing, Vol 25, No. 3 (2008): pg. 167-178. DOI. This article is (C) Emerald and permission has been granted for this version to appear in e-Publications@Marquette. Emerald does not grant permission for this article to be further copied/distributed or hosted elsewhere without the express permission from Emerald. 
NOT THE PUBLISHED VERSION; this is the author's final, peer-reviewed manuscript. The published version may be accessed by following the link in the citation at the bottom of the page.

(c) \# Songs likely to be downloaded in the next 6 months illegally

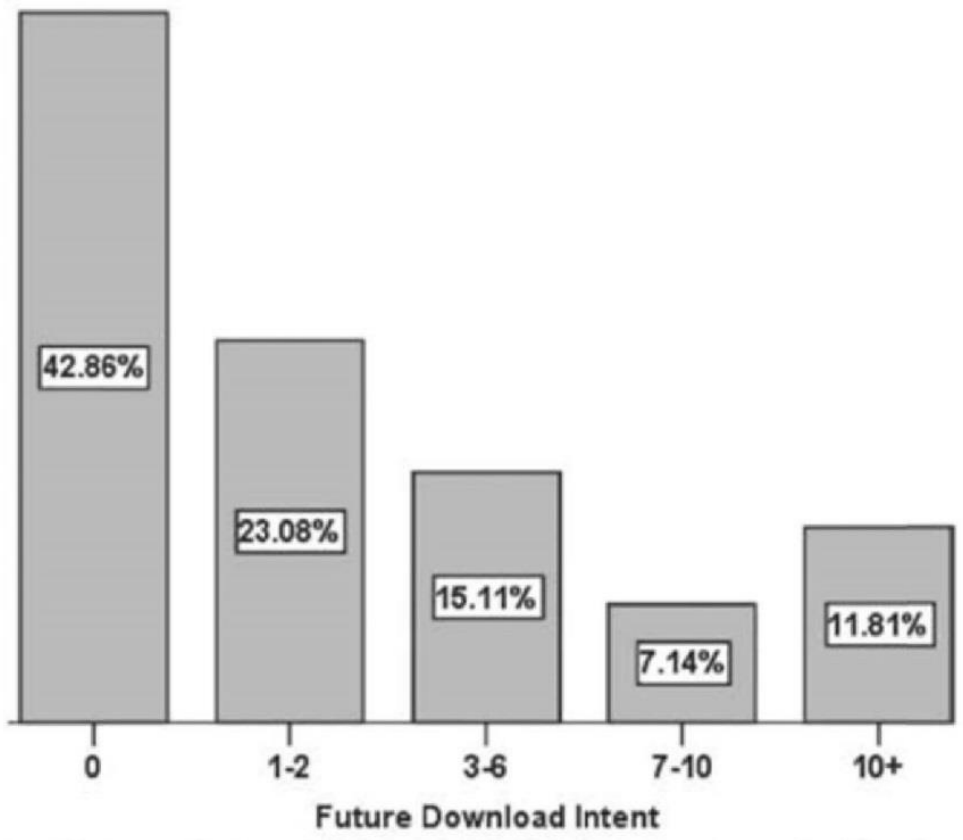

Figure 2: Mean Responses to Ethical Orientation and Attitudes toward Piracy of MP3s

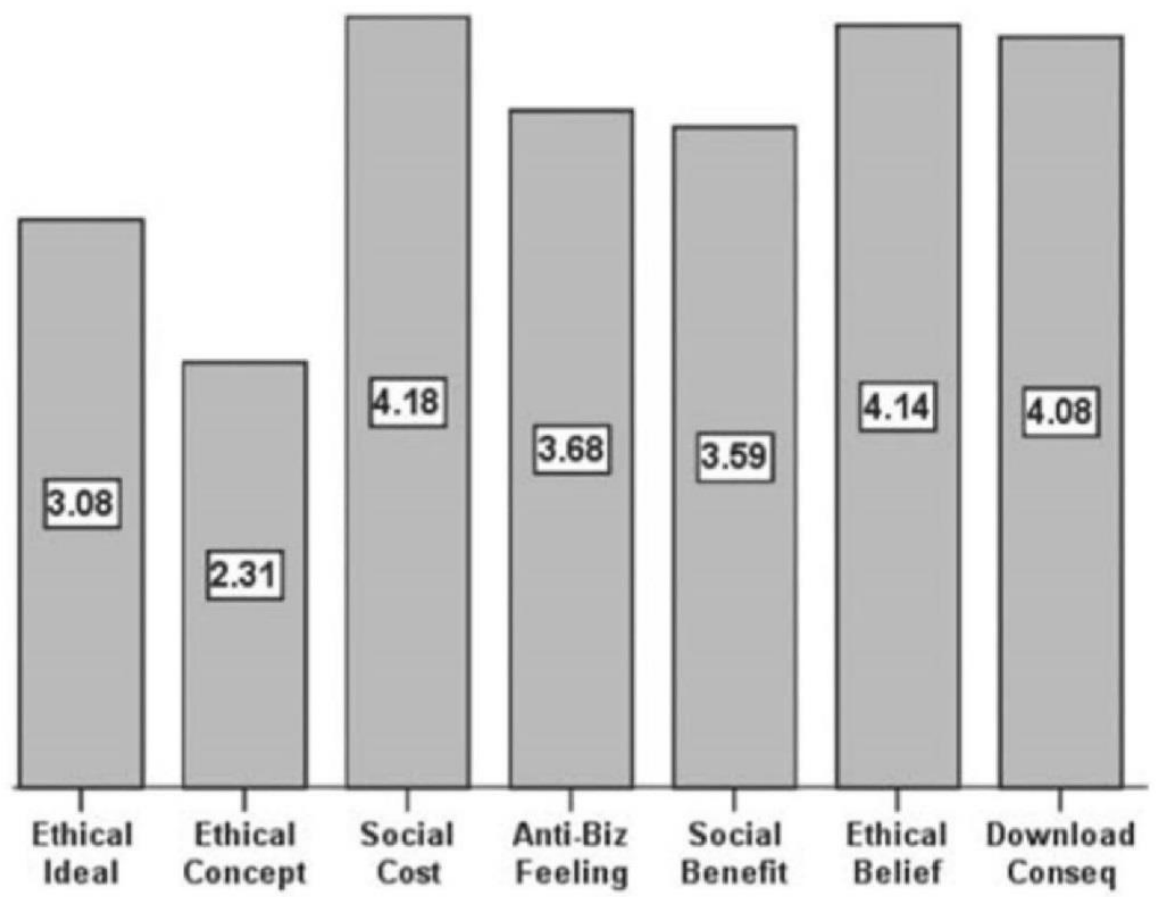

Journal of Consumer Marketing, Vol 25, No. 3 (2008): pg. 167-178. DOI. This article is (C) Emerald and permission has been granted for this version to appear in e-Publications@Marquette. Emerald does not grant permission for this article to be further copied/distributed or hosted elsewhere without the express permission from Emerald. 
NOT THE PUBLISHED VERSION; this is the author's final, peer-reviewed manuscript. The published version may be accessed by following the link in the citation at the bottom of the page.

Note: Mean scores closer to 1 indicate strong agreement and mean scores closer to 7 indicate strong disagreement

\section{Table I: Correlations between Ethical Orientation, Attitudes toward Piracy, and Downloading}

\begin{tabular}{|c|c|c|c|c|}
\hline & \multicolumn{2}{|c|}{ Ethical idealism } & \multicolumn{2}{|c|}{ Ethical self-concept } \\
\hline & Correlation & $p$-value & Correlation & $\rho$-value \\
\hline 1a) Social cost of illegal downloading & 0.26 & 0.00 & 0.12 & 0.02 \\
\hline 1b) Anti-big business sentiment & 0.09 & 0.09 & 0.03 & 0.55 \\
\hline 1c) Social benefits of dissemination & -0.03 & 0.64 & -0.01 & 0.85 \\
\hline 1d) Ethical belief of downloading music & 0.45 & 0.01 & 0.11 & 0.03 \\
\hline 1e) Consequences of downloading & 0.25 & 0.00 & 0.09 & 0.09 \\
\hline 1f) Past illegal downloading music & 0.00 & 0.94 & 0.01 & 0.93 \\
\hline 1g) Past frequency of downloading music & -0.09 & 0.09 & -0.08 & 0.10 \\
\hline 1h) Frequency of paying for downloading music & 0.01 & 0.89 & -0.06 & 0.23 \\
\hline 1i) Future intention of downloading music illegally & -0.06 & 0.23 & -0.03 & 0.55 \\
\hline
\end{tabular}

\section{Table II: Correlations between Intention and Ethical Attitudes of Downloading}

\begin{tabular}{|c|c|c|c|}
\hline & You (mean) & Your peers (mean) & p-value \\
\hline Stealing a CD from a music store with 100 percent certainty of not getting caught? & 6.26 & 5.09 & 0.00 \\
\hline $\begin{array}{l}\text { Stealing a } \mathrm{CD} \text { from a music store with some risk that a invisible security camera might } \\
\text { observe you? }\end{array}$ & 6.77 & 5.86 & 0.00 \\
\hline $\begin{array}{l}\text { Not paying for downloading music from a new CD from a major successful artist who } \\
\text { you believe is very rich because of two previous successful CDs? }\end{array}$ & 3.38 & 2.54 & 0.00 \\
\hline $\begin{array}{l}\text { Not paying for downloading music from a new } C D \text { from an independent artist who is } \\
\text { very artistic but has not made much money on her previous } C D \text { ? }\end{array}$ & 4.08 & 3.09 & 0.00 \\
\hline
\end{tabular}

\section{Table III: Comparison between Respondent's Views about Themselves vs. their Peers for Each Ethical Scenario}

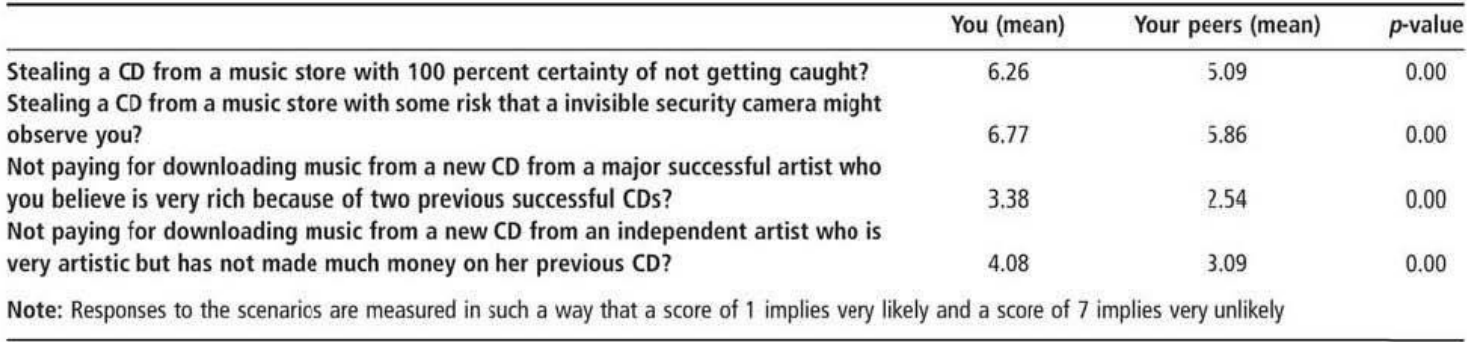

Journal of Consumer Marketing, Vol 25, No. 3 (2008): pg. 167-178. DOI. This article is (C) Emerald and permission has been granted for this version to appear in e-Publications@Marquette. Emerald does not grant permission for this article to be further copied/distributed or hosted elsewhere without the express permission from Emerald. 
NOT THE PUBLISHED VERSION; this is the author's final, peer-reviewed manuscript. The published version may be accessed by following the link in the citation at the bottom of the page.

\section{Table IV: Correlations between Ethical Orientation and Ethical Decisions}

\begin{tabular}{|c|c|c|c|c|}
\hline & \multicolumn{2}{|c|}{ Ethical idealism } & \multicolumn{2}{|c|}{ Ethical self-concept } \\
\hline & Correlation & p-value & Correlation & p-value \\
\hline Stealing a CD from a music store with 100 percent certainty of not getting caught? & -0.19 & 0.00 & -0.21 & 0.00 \\
\hline $\begin{array}{l}\text { Not paying for downloading music from a new CD from a major successful artist who } \\
\text { you believe is very rich because of two previous successful CDs? }\end{array}$ & -0.10 & 0.06 & -0.00 & 0.97 \\
\hline
\end{tabular}

Journal of Consumer Marketing, Vol 25, No. 3 (2008): pg. 167-178. DOI. This article is C Emerald and permission has been granted for this version to appear in e-Publications@Marquette. Emerald does not grant permission for this article to be further copied/distributed or hosted elsewhere without the express permission from Emerald. 